\title{
ASSESSMENT OF GENETIC DIVERSITY OF A REPRESENTATIVE SAMPLE OF FINGER MILLET (ELEUSINE CORACANA (L.) GAERTN.) COLLECTED FROM FOUR DIFFERENT DISTRICTS OF SRI LANKA USING SSR MARKERS
}

Wakista P. W. ${ }^{1}$, Dasanayaka P. N. ${ }^{2 *}$, Illeperuma R. J. ${ }^{1}$ and Perera S. A. C. N. ${ }^{3}$

${ }^{1}$ Genetech, No 54, Kitulwatta Road, Colombo 08, Sri Lanka.

2 Department of Botany, University of Sri Jayewardenepura, Nugegoda, Sri Lanka.

${ }^{3}$ Genetics and Plant Breeding Division, Coconut Research Institute, Lunuwila, Sri Lanka.

\begin{abstract}
Genetic diversity of twenty finger millet germplasm accessions collected from four different districts of Sri Lanka and ex-situ conserved at Plant Genetic Resource Center, Gannoruwa was assessed using ten SSR markers. DNA was extracted from ten days old immature leaves of each finger millet accession and screened for the ten SSR markers. The PCR products were separated on $6 \%$ polyacrylamide gels and visualized by silver staining. The SSR data was analyzed using Power Marker v 3.0. The mean major allele frequency was 0.79 and average PIC value was 0.26 per marker. The number of scorable alleles produced per marker ranged from 1 to 6 with an average of 2.60. Frequency based shared allele distance matrix exhibited genetic distances among finger millet germplasm accessions and these distances varied from 0.06 to 0.70 . Dendrogram constructed on the basis of SSR polymorphism revealed the pattern of genetic relatedness among the twenty finger millet germplasm accessions. The revealed genetic relationships can be used in finger millet germplasm conservation and utilization programs effectively.
\end{abstract}

Key words: finger millet, genetic diversity, germplasm, Simple Sequence Repeats, Sri Lanka 


\section{Introduction}

Finger millet [Eleusine coracana (L.) Gaertn.] is an allotetraploid crop $(2 n=4 x=36)$ and belongs to the family Poaceae and subfamily, Chloridoideae. Finger millet is an important food crop widely cutivated in the arid and semiarid regions of the world, especially in east African and Asian countries including Sri Lanka. It ranks fourth of all millets with an approximately $8 \%$ of the area and $11 \%$ of the production in the world. About 4.5 million tons of grains are produced annually on 5 million hectares of land throughout the world (Nethra et al., 2014). It is commonly known as "Kurakkan" or "Kurahan" in Sri Lanka. The grain contains 70-76\% of carbohydrates, $7-14 \%$ crude protein and particularly rich in methionine, iron and calcium (Barbeau and Hilu, 1993). The crop is adapted to a adverse agroecological conditions and it has the ability to withstand significant level of salinity, its relatively resistant to water logging and has few serious diseases (Dida et al., 2007). Due to its blood glucose lowering quality, it is currently gaining popularity as diabetic relief food. Considering all of these important properties, recently increasing attention is paid to improve finger millet for which the precise information on genetic diversity of the germplasm collection will be the foundation. The ICRISAT (International Crop Research Institute for the Semi Arid Tropics) gene bank holds nearly 6,000 finger millet germplasm accessions from 24 countries, including Sri Lanka. However, in case of finger millet, crop improvement programs are at initial stages and need to focus at large scale. There are very few reports available on the assessment of genetic diversity among finger millet at the national and international level. (Babu, 2015). Sri Lanka is having rich germplasm collection of 249 finger millet accessions at Plant Genetic Resource Center (PGRC), Gannoruwa, Sri Lanka collected from thirteen districts of the Country. These populations may represent an excellent source of adapted germplasm for breeding programs. However little is known about their genetic variability and only a small fraction of this collection has been characterized in several studies (Wakista et al., 2015a, 2015b, 2015c, 2015d, 2016a, 2016b). Being single-locus co-dominant markers with a high degree of length polymorphism, SSRs are the most suitable markers for genotyping a highly self-pollinating crop with a narrow genetic base such as finger millet (Dida et al., 2007). Eighty two SSR markers have been developed for finger millet whereas thirty one of those have been mapped on the linkage map of finger millet by Dida et al., 2007. This study was conducted to assess the genetic diversity among 20 finger millet accessions collected from four districts of Sri Lanka using ten SSR markers by Dida et al., 2007.

\section{Material and Methods}

\subsection{Plant material used}

Seeds of twenty finger millet germplasm accessions collected from four districts of Sri Lanka was obtained from PGRC, Gannoruwa and used for the study (Table 1).

\subsection{DNA extraction and detection of SSR polymorphisms:}

DNA was extracted from ten days old immature leaves using CTAB method (Doyle \& Doyle, 1990) and assayed using 10 microsatellite markers (Table 2). The PCR was set up in a $10 \mu \mathrm{L}$ reaction mixture constituting of $1 \mathrm{x}$ PCR buffer, $2 \mathrm{mM} \mathrm{MgCl} 2,200 \mu \mathrm{M}$ dNTPs, 250 $n M$ from each of the forward and reverse primer, 1 unit Taq DNA polymerase (Promega). The PCR amplification conditions was initial denaturation at $94^{\circ} \mathrm{C}$ for $3 \mathrm{~min}$ followed by 10 cycles of denaturation at $94^{\circ} \mathrm{C}$ for $30 \mathrm{sec}$, touchdown annealing starting at $62^{\circ} \mathrm{C}$ for $30 \mathrm{sec}$, decreasing $0.7^{\circ} \mathrm{C} /$ cycle, extension at $72^{\circ} \mathrm{C}$ for $1 \mathrm{~min}$ followed by 35 cycles at annealing temperature of $55^{\circ} \mathrm{C}$ and final extension at $72{ }^{\circ} \mathrm{C}$ for 
Table 1. Details of finger millet germplasm accessions collected from four different districts of Sri Lanka.

\begin{tabular}{ccc}
\hline Accession No & Accession Name & District \\
\hline 007071 & Kurakkan & Anuradhapura \\
007072 & ThummasKurahan & Anuradhapura \\
007074 & Kurakkan & Anuradhapura \\
007075 & Kurakkan & Anuradhapura \\
007077 & Kurakkan & Anuradhapura \\
000236 & Kurakkan & Hambanthota \\
000238 & Kurakkan & Hambanthota \\
000251 & Kurakkan & Hambanthota \\
000258 & Kurakkan & Hambanthota \\
000275 & Kurakkan & Hambanthota \\
000290 & Kurakkan & Matale \\
000319 & Kurakkan & Matale \\
000340 & SuduNikamal & Matale \\
000350 & Naramani & Matale \\
000353 & KaluNikamal & Matale \\
000495 & Kurakkan & NuwaraEliya \\
000496 & Kurakkan & NuwaraEliya \\
000497 & Kurakkan & NuwaraEliya \\
000504 & Kurakkan & NuwaraEliya \\
000505 & Kurakkan & NuwaraEliya \\
\hline
\end{tabular}

4 min (Dida et al, 2007). PCR products were separated on $6 \%$ polyacrylamide (denaturing) gels and visualized by staining with silver nitrate. The alleles were scored based on the size of each PCR amplified fragment and used for the further analysis.

\subsection{Data analysis}

The major allele frequency, gene diversity, heterozygosity and Polymorphic Information Content (PIC) for each SSR locus were calculated using Power Marker v 3.0 (Liu \& Muse, 2005). Frequency based shared allele distances were calculated and used to construct a dendrogram using UPGMA method with the same software.

\section{Results}

Out of the 10 SSR markers, seven markers (UGEP5, UGEP10, UGEP12, UGEP15, UGEP24, UGEP68 and UGEP77) were polymorphic and the remaining (UGEP11, UGEP18 and UGEP31) were monomorphic. Marker UGEP24 generated the highest number of alleles (6) and markers UGEP11, UGEP18 and UGEP31 generated the least number of alleles (1). The major allele frequency of used SSR markers ranged from 0.42 to 1 with a mean value of 0.79. UGEP11, UGEP18 and UGEP31 showed the highest major allele 
frequency and UGEP24 showed the lowest (Table 3).

Table 2. Information on SSR markers used for the analysis of genetic diversity of finger millet accessions

\begin{tabular}{|c|c|c|}
\hline Marker Name & $\begin{array}{l}\text { Sequence of primer } \\
\left(5^{\prime}-3^{\prime}\right)\end{array}$ & $\begin{array}{c}\text { Product } \\
\text { Length (bp) }\end{array}$ \\
\hline & F - TGTACACAACACCACACTGATG & \\
\hline \multirow[t]{2}{*}{ UGEP5 } & R - TTGTTTGGACGTTGGATGTG & 215 \\
\hline & F - AAACGCGATGAATTTTAAGCTC & \\
\hline \multirow[t]{2}{*}{ UGEP10 } & R - CTATGTCGTGTCCCATGTCG & 400 \\
\hline & F - CCTCGAGTGGGGATCCAG & \\
\hline \multirow[t]{2}{*}{ UGEP11 } & R - AAGACGCTGGTGGAAATAGC & 153 \\
\hline & F -ATCCCCACCTACGAGATGC & \\
\hline \multirow[t]{2}{*}{ UGEP12 } & R - TCAAAGTGATGCGTCAGGTC & 230 \\
\hline & F - AAGGCAATCTCGAATGCAAC & \\
\hline \multirow[t]{2}{*}{ UGEP15 } & R - AAGCCATGGATCCTTCCTTC & 180 \\
\hline & F -TTGCATGTGTTGCTTTTTGC & \\
\hline \multirow[t]{2}{*}{ UGEP18 } & R - TGTTCTTGATTGCAAACTGATG & 318 \\
\hline & F - GCCTTTTGATTGTTCAACTCG & \\
\hline \multirow[t]{2}{*}{ UGEP24 } & R - CGTGATCCCTCTCCTCTCTG & 183 \\
\hline & F - ATGTTGATAGCCGGAAATGG & \\
\hline \multirow[t]{2}{*}{ UGEP31 } & R - CCGTGAGCCTCGAGTTTTAG & 241 \\
\hline & F - CGGTCAGCATATAACGAATGG & \\
\hline \multirow[t]{2}{*}{ UGEP68 } & R - TCATTGATGAATCCGACGTG & 232 \\
\hline & F - TTCGCGCGAAATATAGGC & \\
\hline UGEP77 & R - CTCGTAAGCACCCACCTTTC & 245 \\
\hline
\end{tabular}

Gene diversity varied from 0.00 to 0.73 with an average value of 0.29 . Five SSR markers (UGEP5, UGEP12, UGEP15, UGEP24 and UGEP68) showed more gene diversity than the average value and UGEP24 showed the highest. The heterozygosity ranged from 0.00 to 0.20 and the SSR marker UGEP 05 showed the highest heterozygosity value of 0.20 . The PIC values ranged from 0.00 to 0.69 and the average PIC value was 0.26 . SSR marker UGEP24 showed the highest PIC value (0.69) and UGEP11, UGEP18 and UGEP 31 sowed the PIC value of 0.00 (Table 3).
Frequency based shared allele distance matrix exhibited distances between finger millet germplasm accessions. These distances varied from 0.056 to 0.70 . The highest distance was observed between 000504 ("Kurakkan" from Nuwara Eliya district) and 000251 ("Kurakkan" from Hambantota district) and the lowest between 007074 ("Kurakkan" from Anuradhapura district) and 007077 (Kurakkan from Anuradhapura district), 000497 ("Kurakkan" from Nuwara Eliya district). 
Dendrogram constructed on the basis of SSR polymorphism revealed the pattern of relatedness among 20 finger millet germplasm accessions (Figure 1). Two accessions $\quad 000504$ and 000505 "Kurakkan" from Nuwara Eliya district) out grouped at the first level from other accessions showing the genetic relatedness between them and the high genetic distance from the rest of the accessions. Accessions 000350, 000251, 000258 and 000275,000495 and 000496, 000236, 000353, 007075 separated from remaining accessions at the second, third, fourth, fifth, sixth, seventh and eighth levels respectively. Clear separation of remaining nine accessions into two sub clusters was observed. First sub cluster comprised of three accessions $(000319,000238$ and 000290 ) collected from Matale and Hambanthota districts and second cluster comprised of six accessions (000340, 000497, 007071, 007072, 007074 and 7077) collected from Matale, Nuwara Eliya and Anuradhapura districts.

Table 3. Summary of statistics obtained by power marker analysis for finger millet accessions using SSR markers

\begin{tabular}{ccccccc}
\hline & $\begin{array}{c}\text { Major Allele } \\
\text { Marker }\end{array}$ & $\begin{array}{c}\text { Genotype } \\
\text { Frequency }\end{array}$ & $\begin{array}{c}\text { Allele } \\
\text { No }\end{array}$ & $\begin{array}{c}\text { Gene } \\
\text { Diversity }\end{array}$ & Heterozygosity & PIC \\
\hline UGEP5 & 0.75 & 4.00 & 3.00 & 0.39 & 0.20 & 0.33 \\
UGEP10 & 0.90 & 2.00 & 2.00 & 0.18 & 0.00 & 0.16 \\
UGEP11 & 1.00 & 1.00 & 1.00 & 0.00 & 0.00 & 0.00 \\
UGEP12 & 0.70 & 5.00 & 4.00 & 0.48 & 0.10 & 0.44 \\
UGEP15 & 0.50 & 4.00 & 4.00 & 0.59 & 0.00 & 0.50 \\
UGEP18 & 1.00 & 1.00 & 1.00 & 0.00 & 0.00 & 0.00 \\
UGEP24 & 0.42 & 6.00 & 6.00 & 0.73 & 0.00 & 0.69 \\
UGEP31 & 1.00 & 1.00 & 1.00 & 0.00 & 0.00 & 0.00 \\
UGEP68 & 0.80 & 2.00 & 2.00 & 0.32 & 0.00 & 0.27 \\
UGEP77 & 0.89 & 2.00 & 2.00 & 0.19 & 0.00 & 0.17 \\
Mean & 0.79 & 2.80 & 2.60 & 0.29 & 0.03 & 0.26 \\
\hline
\end{tabular}

\section{Discussion}

In general, use of SSR markers to study the genetic diversity in millets is considered as a most appropriate technique providing useful molecular data compared to other marker systems hence gained acceptance world-wide (Stich et al., 2010). In the present study out of the 10 SSR markers seven markers were polymorphic and other three were monomorphic across the twenty genotypes. The number of scorable alleles produced per marker ranged from 1 to 6 with the average of 2.60 . It may be due to the fact that finger millet is a highly self-pollinating crop. A study conducted by Nethra et al., 2014 to assess the genetic diversity of 24 finger millet accessions of India using 35 SSR markers reports the same range of 1 to 6 alleles per locus of the present study. Range of 3 to 23 alleles per locus was reported in a study of 340 finger millet accessions of East Africa using 23 SSR markers (Manyasa et al., 2015). The generation of high number of alleles per locus may be due to the presence of unique alleles present in the wild genotypes, which have been lost during the cultivation and adaptation to 
favorable conditions (Nethra et al., 2014).

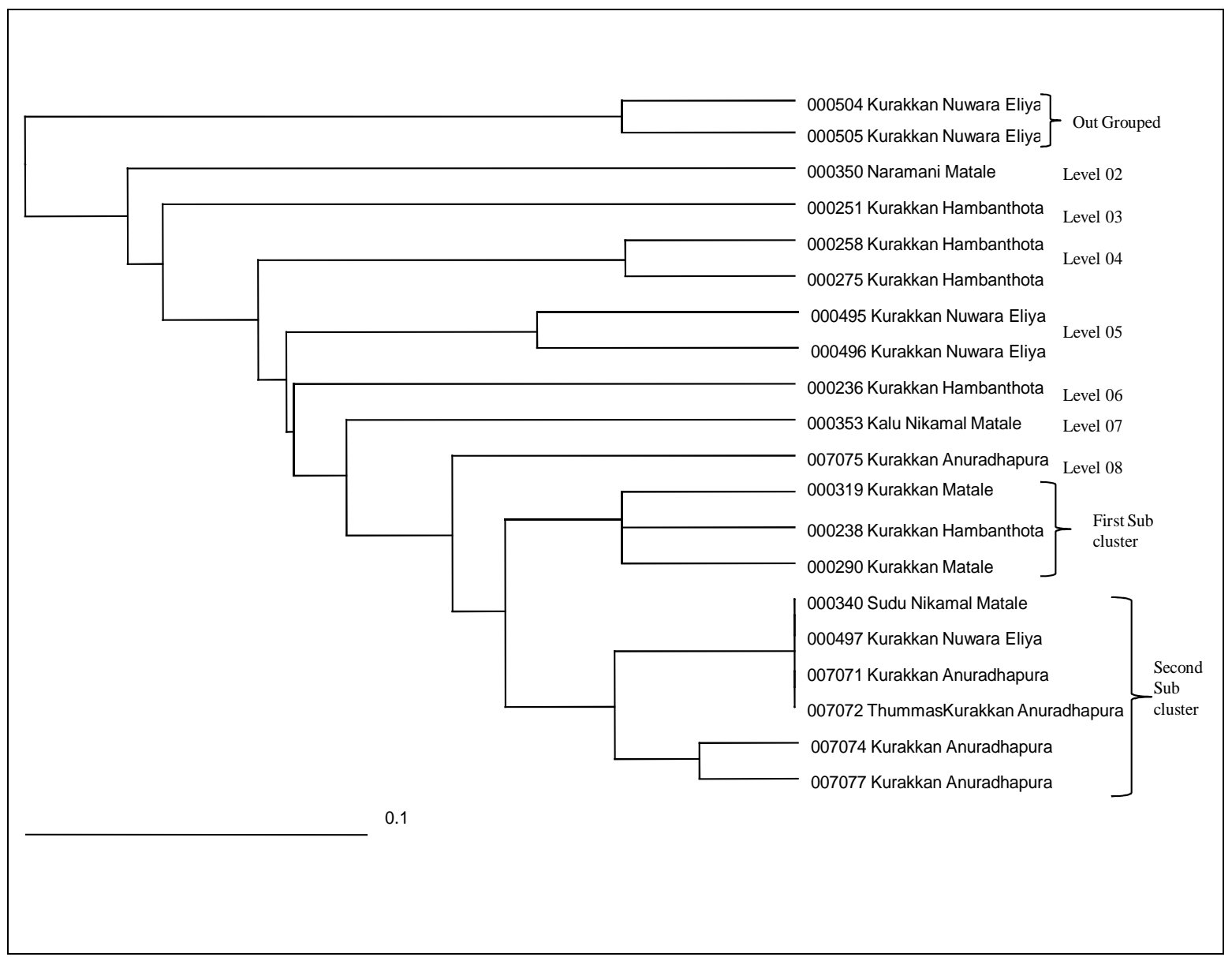

Figure 1. Dendrogram of finger millet germplasm accessions constructed based on SSR marker analysis.

In the present study, PIC values of the SSR markers ranged from 0.00 to 0.69 and the average PIC value was 0.26 . Ramakrishnan et al., (2016) have assessed genetic diversity of 128 Indian and non-Indian genotypes of finger millet using 87 genomic SSR markers and reported PIC values ranging from 0.32 to 0.64 with average PIC value of 0.44 .

Gene diversity of the present study varied from 0.00 to 0.73 with an average value of 0.29 . The highest gene diversity of 0.73 was with the marker UGEP24 followed by 0.59 of UGEP15. Five out of the ten markers showed more gene diversity than the average value. Ramakrishnan et al., (2016) have observed gene diversity values $(0.02$ 0.35 with an average value of 0.14 ).

The heterozygosity values observed in the present study (ranging from 0.00 to 0.20 with an average of 0.03 ) is in agreement with heterozygosity values (ranging from 0 to 0.26 with an average heterozygosity value of 0.11 ) observed by Ramakrishnan et al., (2016). Heterozygosity is due to the fact that some markers might have detected/ amplified more than a single locus or amplified segments on two different genomes, considering that finger millet is an allotetraploid with two genomes (AA and BB) (Dida et al., 2008).

Four accessions (000340: Sudu Nikamal from Matale, 000497: Kurakkan from 
Nuwara Eliya, 007071: Kurakkan from Anuradhapura and 007072: Thummas Kurahan from Anuradhapura) showed genetic similarity between them irrespectively to the geographical region/district they have been collected. Even though the accessions were selected from four geographically distant districts having contrastingly different environmental conditions, it was not reflected in the clustering pattern, no impact of that was seen in the pattern of clustering. Some of the accessions with the same accession names showed high genetic distances between them (E.g.: 000504 "Kurakkan" from Nuwara Eliya district and 000251 Kurakkan from Hambantota district) where genetic relatedness and similarity were observed between accessions with different accession names (E.g.: 000340 "Sudu Nikamal" from Matale district, 000497 "Kurakkan" from Nuwara Eliya district). This shows the accession names given in the conservation program also had no impact on the clustering pattern of the accessions and the accessions names are not clear reflections of the genetic makeup of the accessions.

\section{Conclusion}

All the above findings indicate the importance of characterization of the germplasm in identifying their true genetic relationship. Accessions with highest genetic distances identified by the study can be used as potential parents in breeding programs.The accessions identified to be having unique alleles can be conserved as core accessions. The accessions with different accession names/different locations of collection which were identified to be genetically similar can be considered as duplications occurred in conservation programs. The said two findings can be used to avoid duplications and fine tune the conservation programs of the crop.The study is being continued to assess the genetic diversity of all 249 finger millet germplasm accessions conserved at
PGRC, Gannoruwa with an increased number of SSR markers and with morphological markers, which will lead to findings that assist the conservation and improvement of the crop in a more accurate and broader manner.

\section{Acknowledgements}

i. National Science foundationGrant Number: RG/2011/BT/09

ii. Plant Genetic Resource Center, Gannoruwa, Sri Lanka
iii. Department of Botany, University of Sri Jayawardenepura

iv. Genetech, No:54, Kithulwatta Road, Colombo 08.

\section{References}

Babu, B.K. (2015) Molecular Marker Technology for Finger Millet Crop Improvement- An underUtilized, Food and Nutritional, Aperito Journal of Advanced Plant Biology 1: 104.

Barbeau, W.E, Hilu, K.W. (1993) Protein, calcium, iron and amino acid content of selected wild and domesticated cultivars of finger millet, Plant Foods Human Nutrition and Dietetics 43: 97-104.

Dida, M.M., Wanyera, N., Dunn, M.L.H., Bennetzen, J.L., Gale, M.D., Devos, K.M. (2007) The genetic map of finger millet, Eleusinecoracana, Theoretical and Applied Genetics 114: 321-332.

Doyle, J.J., Doyle, J.L (1990) Isolation of plant DNA from fresh tissue, Molecular Ecology 4: 129-131.

Liu, K., Muse, M. (2005) Power Marker: An integrated analysis environment for genetic marker analysis, Bioinformatics 21: 2128-2129.

Manyasa, E.O., Tongoona, P., Shanahan, P., Mgonja, M.A, De Villers S. (2015) Genetic diversity in East African finger millet (Eleusine coracana (L.) Gaertn.) landraces based on SSR markers and some qualitative traits, Plant 
Genetic Resources: Characterization and Utilization 13(1): 45-55.

Nethra, N., Gowda, R., Prasad, S.R., Hittalmani, S., Gowda, P.H.R., Chennekeshawa, B.C. (2014) Utilization of SSR to estimate the degree of genetic relationships in finger millet (EleusinecoracanaL. Gaertn.) genotypes and sub species, SABRAO Journal of Breeding and Genetics 46 (1): 136-149.

Ramakrishnan, M., Antony, C. S., Duraipandiyan, V., Al-Dhabi, N.A., Ignacimuthu, S. (2016) Assessment of genetic diversity, population structure and relationships in Indian and nonIndian genotypes of finger millet (Eleusinecoracana (L.)Gaertn) using genomic SSR markers, Springerplus 5: 120.

Stich, B., Haussmann, B., Pasan, R., Bhosale, S., Hash, C.T., Melchinger, A., Parzics, H. (2010) Patterns of molecular and phenotypic diversity in pearl millet [Pennisetumglaucam (L.) R. Br.] from West and Central Africa and their relation to geographical and environmental parameters. BMC Plant Biology 10: 216.

Wakista, P.W., Dasanayaka, P.N., Illeperuma, R.J., Perera, S.A.C.N. (2015a) SSR Markers revealed genetic diversity of some finger millet accessions collected from six districts of Sri Lanka. 7th Annual Scientific Sessions of Institute of Biochemistry, Molecular Biology and Biotechnology, 21 May 2015, Institute of Biochemistry, Molecular Biology and Biotechnology, Colombo, Sri Lanka, p. 34.

Wakista, P.W., Dasanayaka, P.N., Illeperuma, R.J., Perera, S.A.C.N., Bandara, S.P. (2015b) Compilation of an informative SSR marker set for molecular characterization of finger millet
(Eleusine coracana L.) germplasm accessions of Sri Lanka. International Conference on Multidisciplinary Approaches (ICMA), 11-12 th December 2015, Golden Rose Reception Hall, Borelesgamuwa, Sri Lanka, p. 217.

Wakista, P.W., Dasanayaka, P.N., Illeperuma, R.J., Perera, S.A.C.N. (2015c) SSR marker based molecular characterization of finger millet accessions of India and Anuradhapura district of Sri Lanka, 20th International Forestry and Environment Symposium, 16-17th October 2015, Club Hotel Dolphin, Waikkal, Negombo, Sri Lanka, p. 40.

Wakista, P.W., Dasanayaka, P.N., Illeperuma, R.J., Perera, S.A.C.N. (2015d) SSR Marker based genetic relatedness of some finger millet (Eleusine coracana) accessions of Sri Lanka, 71 st Scientific Sessions of the Sri Lanka Association for the Advancement of Science, 2-4th December 2015, University of Sri Jayewardenepura, Sri Lanka, p.15.

Wakista, P.W., Dasanayaka, P.N., Illeperuma, R.J., Perera, S.A.C.N. (2016a) SSR marker based genetic diversity of some finger millet germplasm accessions having different geographical origins, International Conference On Green Technologies for Sustainable Ecosystems (ICGTSE-2016), 26-27th February 2016, Bangalore, India, p. 91.

Wakista, P.W., Dasanayaka, P.N., Illeperuma, R.J., Perera, S.A.C.N. (2016b) Assessment of genetic diversity among ex-situ conserved finger millet (Eleusine coracana L.) accessions of Nuwara Eliya district of Sri Lanka, 36th Annual Sessions of The Institute of Biology Sri Lanka, 30th September 2016, Construction Industry Development Authority (CIDA), Colombo 07, Sri Lanka, p. 40. 